\title{
The Rise of Note-Taking in Early Modern Europe
}

\section{Citation}

Blair, Ann. 2010. The rise of note-taking in Early Modern Europe. Intellectual History Review 20(3): 303-16.

\section{Published Version}

doi:10.1080/17496977.2010.492611

\section{Permanent link}

http://nrs.harvard.edu/urn-3:HUL.InstRepos:4774908

\section{Terms of Use}

This article was downloaded from Harvard University's DASH repository, and is made available under the terms and conditions applicable to Open Access Policy Articles, as set forth at http:// nrs.harvard.edu/urn-3:HUL.InstRepos:dash.current.terms-of-use\#OAP

\section{Share Your Story}

The Harvard community has made this article openly available.

Please share how this access benefits you. Submit a story.

Accessibility 


\title{
THE RISE OF NOTE-TAKING IN EARLY MODERN EUROPE
}

\author{
Ann Blair ${ }^{1}$
}

The early modern period holds a special place in the history of European note-taking because direct evidence from surviving notes from the ancient and medieval periods is limited whereas it is often remarkably abundant starting in the $15^{\text {th }}$ century. I focus on two kinds of causal factors to explain this shift: on the one hand, the widespread availability of paper as a durable medium that was much less expensive than parchment made possible the long-term survival of notes down to the present; on the other hand, habits of taking and saving notes formed an equally essential prerequisite to the survival of multi-volume collections of notes among humanist scholars as well as scientific observers and travellers. Humanist and Jesuit pedagogues and institutions (like the Jesuit order, as examined by Paul Nelles in this volume, or the academies or governments that sponsored scientific expeditions) promoted the ideal of stockpiling notes from one's reading and experience, even if one did not have an immediate use to which to put them, in order to make them available for future use by oneself or by others. As a result we have large collections of notes by early modern scholars and travellers which have survived archived on paper, whether or not they were ever consulted again or used in the composition of published works.

Note-taking has likely existed in some form in most literate contexts, but since notes were hardly ever transmitted by repeated copying they do not survive when they were written on

\footnotetext{
${ }^{1}$ Warm thanks to Richard Yeo for his energy and leadership in organizing the conference in July 2008 and in initiating this special issue. I am grateful for his friendship, insightful comments and exacting editing throughout our collaboration.
} 
temporary or fragile surfaces such as wax tablets or papyrus. On the other hand, when broadly conceived as a close relative of record-keeping, note-taking could include some of the earliest known forms of writing, starting with the stones marked with notches in Mesopotamia to record grain storage and trade (ca $3500 \mathrm{BCE}$ ) and the clay tablets generated by the administration of the Assyrian empire in the $3^{\text {rd }}$ millennium BCE. ${ }^{2}$ Record-keeping by administrations (states and churches) as well as merchants (and, in later periods, lawyers) shifted in the following millennia to new media: first, papyrus from Egypt which was exported throughout the ancient Mediterranean; then parchment, better suited than papyrus (which frays when cut into sheets) to the pages of the codex form which became standard between $2^{\text {nd }}$ and $4^{\text {th }}$ centuries; and finally paper, introduced from Islam to Southern Europe in the $13^{\text {th }}$ century and North of the Alps in the $14^{\text {th }}$ century. The interconnection between different kinds of record-keeping and note-taking in different contexts is a vast and rich field which has only begun to be studied. In this special issue we focus on note-taking from scholarly reading and scientific observation. Each author has come to this topic through different avenues, but our shared focus on note-taking is reinforced by recent developments in the history of reading on the one hand and on the other hand by a new emphasis in the history of science on practices and the repeated and often mundane tasks that make scientific work possible.

Since the 1980s scholars in history and the literatures in alliance with book professionals in libraries and the rare book world have re-emphasized the value of studying the material form in which a text was known to its readers in order to assess what it meant to them. Physical copies

${ }^{2}$ D. Schmandt-Besserat, How Writing Came About (Austin: University of Texas Press, 1996); E. Posner, Archives in the Ancient World (Cambridge, Mass: Harvard University Press, 1972). 
of books are full of clues about who read them and how, including the size of the book, the quality of its production, the nature of the binding, any texts that were bound together and signs of use left by readers, such as marks of possession, underlining or flagging in the text, and especially reading notes entered in the margins and flyleaves. Marginal reading notes were generally preserved unintentionally with the book itself -at least as long as they were not whitewashed by collectors in the nineteenth and early twentieth centuries who preferred to own and sell books in pristine condition. ${ }^{3}$ The study of marginal annotations led historians of the early modern book to understand the broader cycle of note-taking in which passages annotated in books were often copied into notebooks or onto loose leaves under topical headings to facilitate later retrieval. The process was called 'commonplacing' or 'excerpting', terms coined in English in this period, from Latin models. ${ }^{4}$

${ }^{3}$ For an entry into annotations in early modern printed books see W.H. Sherman, Used Books: Marking Books in Renaissance England (Philadelphia: University of Pennsylvania Press, 2008) and R. Stoddard, Marks in Books, Illustrated and Explained (Cambridge MA: Houghton Library, 1985); for the modern period see Heather Jackson, Marginalia:readers writing in books (New Haven:Yale University Press, 2001).

${ }^{4}$ Oxford English Dictionary first attests 'commonplace' (from the Latin 'locus communis') as noun in 1531 and a verb in 1656; 'excerpt' (from the Latin 'excerpere') as a verb in 1536 and a noun in 1656. On humanist note-taking see A. Blair, 'Humanist methods in natural philosophy: the commonplace book', Journal of the History of Ideas, 53 (1992), 554-551; 'Bibliothèques portables: les recueils de lieux communs dans la Renaissance tardive', in Le pouvoir des bibliothèques. La mémoire des livres en Occident, edited by M. Baratin and C. Jacob (Paris: Albin Michel, 1996), 84-106; on the $18^{\text {th }}$ century, Lire, copier, écrire, edited by E. Décultot (Paris: Centre National de la Recherche 
At the same time specialists of individual literary or scientific figures whose notebooks or drafts survive have also studied these for clues about the evolution of that individual's thought and writing. In literature genetic criticism studies the development of a work from reading notes and drafts; this approach is most feasible after the mid- $19^{\text {th }}$ century, once national libraries started amassing the working papers of authors, either by bequest or by purchase. ${ }^{5}$ In the history of science too scholars have attended to surviving notebooks or laboratory logs in order to trace the development of a particular scientist's intellectual development. ${ }^{6}$ Unpublished papers of this

Scientifique, 2003) and A. te Heesen, 'Accounting for the natural world : double-entry bookkeeping in the field', in Colonial botany. Science, commerce, and politics in the early modern world, edited by $\mathrm{L}$. Schiebinger and Cl. Swan (Philadelphia : University of Pennsylvania Press, 2005), 237-251.

${ }^{5}$ For an entry into genetic criticism see P.-M. de Biasi et al., Pourquoi la critique génétique? Méthodes, théories (Paris: CNRS Editions, 1998) and M. Espagne, De l'archive au texte: recherches d'histoire génétique (Paris: Presses Universitaires de France, 1998). On the problems of literary manuscripts left unfinished, see Le manuscrit inachevé. Ecriture, création, communication, edited by L. Hay (Paris: Editions du CNRS, 1986).

${ }^{6}$ On scientific note-taking see L. Daston, "Taking note(s)", Isis 95 (2004), 443-448. On writing technologies in the experimental sciences: F. Holmes, 'Scientific writing and scientific discovery', Isis, 78 (1987), 220-235; Reworking the Bench. Research Notebooks in the History of Science, edited by F. L. Holmes, J. Renn, and H.-J. Rheinberger (Dordrecht : Kluwer Academic Publishers, 2003); U. Klein, 'Paper tools in experimental cultures. The case of Berzelian formulae', Studies in History and Philosophy of Science 32 (2001), 265-312. On Darwin's notebooks : H. E. Gruber, Darwin on Man. A Psychological Study of Scientific Creativity, 2nd ed. (Chicago: Chicago University Press, 1981); and 'Going the Limit: Toward the construction of Darwin's theory (1832-1839)', in The Darwinian Heritage, edited by D. Kohn 
kind are often presumed to offer a more honest view of their authors' thought and development. ${ }^{7}$ Without denying the interest of notebooks for insights into individuals, the cultural historian can also study note-taking not as peculiarly unconstrained, but rather as the product of practices of reading and writing taught in school and reinforced by various cultural models.

Our purpose in this collection is to analyze note-taking not on the scale of the individual, but as a practice that was broadly shared within a context variously defined by profession or occupation, time and place or other cultural factors, such as religion. By pooling together as we do here studies of specific cases we seek to build a broader picture of the ideals and practices of note-taking, of what changed and what remained constant, between the Renaissance and the early $19^{\text {th }}$ century. The discipline of history develops by calling attention to new sources and asking new questions of well-known materials, and this collective attention to note-taking promises to contribute in both of those ways. By looking at practices of note-taking for their own sake we can get a better idea of how people performed intellectual work in the past, what caught their attention and how they moved from reading to producing a finished work, often via notetaking. Of course surviving notes never report all the mental processes involved but they take us perhaps as close as the historian can hope to get. Once we know more about the norms of notetaking in various contexts--how students or various professionals were taught or expected to take notes--then we can also help evaluate an individual collection of notes, and assess how idiosyncratic or representative an individual's note-taking methods were in his or her context.

(Princeton: Princeton University Press, 1985), 9-34.

${ }^{7}$ D. van Hulle and W. van Mierlo, 'Reading notes: introduction', in Variants--the Journal of the European Society for Textual Scholarship, 2/3 (2004),1-6, 2. 
Comparisons with note-taking in Antiquity and the Middle Ages:

It is remarkable how many collections of notes survive starting in Renaissance and how large these collections can be. We have many volumes of notes by humanists. For example the manuscripts of Angelo Poliziano (1454-94) were dispersed at his death among students and peers, who variously wished to own, read or publish them, often under Poliziano's name but also sometimes without properly attributing them. ${ }^{8}$ For the leading French humanist Guillaume Budé (1468-1540), seven volumes of notes are extant, and from the later Joseph Justus Scaliger (15401609), a few dozen volumes-- subsets of the notes each scholar had originally accumulated. ${ }^{9}$ Among natural historians, Ulisse Aldrovandi (1522-1605) left more than 400 volumes of manuscripts, many of them comprising notes on slips of paper glued into notebooks under topical headings. The French nobleman and antiquarian Nicolas Fabri de Peiresc (1580-1637) favored loose

${ }^{8}$ For example in 1498 the great humanist printer Aldus Manutius articulated in print the suspicion that some contemporaries had absconded with Poliziano manuscripts that had gone missing in order to publish them as their own: 'Sed utinam et secundam centuriam Miscellaneorum et Epiphyllidas, et in Terentium, in Statium, in Quintilianum ingeniosas et doctas annotationes, et alia quam pluriam ex quibus vel centum facere centurias potuisset, habuissemus ... quae (ut audio) quidam florentiae occultant, ut edant pro suis'. A. Poliziani, Opera omnia (Venice, 1498), f. 1 verso, as quoted in I. Maïer, Les manuscrits d'Ange Politien (Geneva: Droz, 1965), 8.

${ }^{9}$ A. Grafton, 'How Guillaume Budé Read his Homer', in Commerce with the Classics: Ancient Books and Renaissance Readers (Ann Arbor: University of Michigan Press, 1997), 169, and the list of manuscripts in Joseph Scaliger. A Study in the History of Classical Scholarship, 2 vols (Oxford: Clarendon Press, 1993), vol. 2, 753-55. 
leaves kept in bundles; although his study seemed to be a mess, he reportedly could find his way around his papers provided no one had disrupted them. ${ }^{10}$ A professor of medicine and natural philosophy at various German universities, Joachim Jungius (1584-1657), amassed perhaps the largest collection of notes of all, estimated at some 150,000 pages, of which 45,000 are extant. ${ }^{11} \mathrm{~A}$ remarkable cluster of personal archives survive from $17^{\text {th }}$-century England, including those of Samuel Hartlib and the Earl of Shaftesbury and Royal Society members Robert Boyle, John Evelyn, Robert Hooke, John Locke, Isaac Newton (which the Royal Society helped to preserve). ${ }^{12}$ Recent

${ }^{10} \mathrm{P}$. Gassendi, The mirrour of true nobility and gentility being the life of the renowned Nicolaus Claudius Fabricius lord of Peiresk, senator of the parliament at Aix, Englished by W. Rand (London, 1657), book 6,197.

${ }^{11}$ For descriptions of Aldrovandi's manuscripts see Catalogo dei manoscritti di Ulisse Aldrovandi, edited by L. Frati, with A. Ghigi and A. Sorbelli (Bologna: N. Zanichelli, 1907). On Jungius see C. Meinel, 'Enzyklopädie der Welt und Verzettelung des Wissens: Aporien der Empirie bei Joachim Jungius', in Enzyklopädien der frühen Neuzeit Beiträge zu ihrer Forschung (Tübingen: Niemeyer, 1995), 162-87, at 166, 168.

${ }^{12}$ See Archives of the Scientific Revolution. The formation and exchange of ideas in seventeenthcentury Europe, edited by M. Hunter (Woodbridge, Suffolk: The Boydell Press, 1998) for articles on the papers of Samuel Hartlib, Robert Boyle, Robert Hooke, Isaac Newton and Leibniz. On Evelyn see T. Hofmann and J. Winterkorn, F. Harris and H. Kelliher, 'John Evelyn's archive at the British Library', in John Evelyn in the British Library (London: The British Library, 1995), 11-73 and G. Mandelbrote, 'John Evelyn and his books' in John Evelyn and his milieu, edited by F. Harris and M. Hunter (London: The British Library, 2003), 71-94. On John Locke see R. Yeo, 'John Locke's 'New method' of commonplacing: Managing Memory and Information', Eighteenth- 
studies of the notebooks compiled by the London merchant Clement Draper (c. 1541-1620) during his thirteen years of incarceration for debt or the twenty surviving volumes of notes of Sir William Drake (1606-69), an otherwise unremarkable English gentleman during the civil war, suggest that collections of notes can be studied well beyond the famous few who have been the focus of most attention so far. ${ }^{13}$ These collections, left unattended for centuries in libraries and archives, attest to the staying power of ink on paper and to the voracious appetites of many early modern Europeans for stockpiling information in note form, even if they never turned their notes into fodder for publication--while some abundant note-takers published abundantly, others (including Peiresc and Drake for example) did not.

I emphasize the novelty of humanist excerpting, but Renaissance pedagogues invoked ancient precedent for their practices, however limited their evidence for it was. In their widely reprinted manuals on excerpting the Jesuits Francesco Sacchini (1570-1625) and Jeremias Drexel (1581-1638) cited ancient antecedents for note-taking. These included the abundant production of ancient polygraphs like Didymus the Brazen-Gutted who reportedly composed some 3500 volumes (or papyrus rolls) in Alexandria of the $1^{\text {st }}$ ct BCE, about whom Drexel concluded that 'he must have excerpted'. Humanists were on firmer ground in invoking the passage in which

Century Thought 2 (2004), 1-38. The Hartlib Papers are on CD-ROM (second edition, Sheffield: HROnline, 2002). On Peiresc see P. N. Miller, Peiresc's Europe: learning and virtue in the seventeenth century (New Haven: Yale University Press, 2000).

${ }^{13}$ D. Harkness, The Jewel House. Elizabethan London and the Scientific Revolution (New Haven: Yale University Press, 2007), ch. 5. K. Sharpe, Reading Revolutions: the Politics of Reading in Early Modern England (New Haven: Yale University Press, 2000). 
Pliny the Younger described his uncle's working methods in his Epistles. ${ }^{14}$ The text had been recently recovered by the humanists and the passage remains still today a principal focus of modern analysis of ancient note-taking. In it the younger Pliny emphasized, with some bemusement, how the elder Pliny devoted every possible moment to study, sleeping only a minimum and arranging to be read to while eating, travelling or bathing. He took notes on every book that he read, reportedly quipping that 'there was no book so bad that some good could not be got out of it'. As a result Pliny the Younger inherited from his uncle 160 commentarii, or volumes of sorted notes 'written in a minute hand on both sides of the page, so that their number is really doubled'. These his uncle had refused to sell when he was reportedly offered a tidy sum by one Larcius Licinus when he was serving as procurator in Spain. ${ }^{15}$ For the humanists the passage offered ancient antecedent proving

${ }^{14}$ Didymus's output is reported as 4000 books in Seneca, Letters, 88 and more than 3500 books in Athenaeus, Deipnosophistae, 4.139. On the meanings of "book" see A. Grafton and M. Williams, The Transformation of the Book: Origen, Eusebius and the Library of Caesarea (Cambridge, Mass: Belknap Press of Harvard University Press, 2006), 10-12. See Jeremias Drexel, Aurifodina artium et scientiarum omnium (Antwerp: vidua Ioannis Cnobarri, 1638), ch. 7 and p. 65 and Francesco Sacchini, De ratione libro cum profectu legendi libellus (Ingolstadt: ex typographeo Ederiano, 1614) ch. 11, e.g. p. 76.

${ }^{15}$ Pliny the Younger, Letters and Panegyricus, tr. B. Radice. 2 vols. (Cambridge, MA: Harvard University Press, 1969), III, 5: vol. 1, 172-79, at 177. The 400,000 sesterces Pliny was reportedly offered for his notes was the property valuation required of the lower section of the equestrian class, a very small and wealthy nobility in Pliny's time. Licinus was the Praetorian Legate in Spain, c. 73. See R. MacMullen, Roman Social Relations, 50 B.C. to A.D. 284 (New Haven and London: Yale University Press, 1974), 293-94. I am grateful to John Bodel for this reference. 
the value of taking and saving large collections of notes. For the historian, the passage also highlights how exceptional a note-taker Pliny the Elder was in his day.

Hardly any notes survive from antiquity: ancient papyrus had a life expectancy of two to three hundred years under normal circumstances and notes did not carry enough authority to warrant the attention of an early Christian copyist. A few fragments survive due to exceptional circumstances: some notes and drafts of treatises by the Epicurean philosopher Philodemus (110-40 BCE) were preserved under seventy feet of volcanic ash at Herculaneum; a papyrus recovered in Toura, Egypt, in the $20^{\text {th }}$ century contains notes taken on a polemical work by the Church father Origen (185-254), including both faithful excerpts of varying lengths and notes made by abridgment from his Against Celsus. ${ }^{16}$ For ancient note-taking we are thus mostly dependent on contemporary descriptions like Pliny's and on the finished works that the notes made possible. As reconstructed by modern scholars, the commentarii that Pliny the Younger describes would likely have been compiled from texts that Pliny read (or had read to him). The commentarii were second-order notes, sorted under topical headings and copied onto papyrus for long-term preservation from an earlier stage of temporary notes (adnotationes) that recorded passages of interest on wax tablets. Notes at any stage might have been taken by Pliny himself or by an educated slave taking dictation from Pliny. ${ }^{17}$ This method of note-taking is corroborated by the way in which some other ancient authors incorporated excerpts from existing works into their own: analyses of the

${ }^{16}$ See M. Gigante, Philodemus in Italy: The Books from Herculaneum, translated by D. Obbink (Ann Arbor: University of Michigan Press, 1995), 16 and T. Dorandi, Le stylet et la tablette. Dans le secret des auteurs antiques (Paris: Les Belles Lettres, 2000), 45.

${ }^{17}$ See Dorandi, ch. 2 and J. E. Skydsgaard, Varro the Scholar: Studies in the First Book of Varro's De Re Rustica (Copenhagen: Einar Munksgaard, 1968), 115. 
Lives of Plutarch and of Diogenes Laertius suggest that they too relied on notes taken from different sources and sorted topically. ${ }^{18}$ But it is not clear whether any ancient author other than Pliny stockpiled notes beyond their use for a particular work, nor are historians likely to ever fully reconstruct ancient note-taking practices.

From the Middle Ages when the durable medium was parchment made from animal skin, notes could have survived down to the present. Interestingly, though, medieval manuscripts comprising collections of personal reading notes are not common, even after the $13^{\text {th }}$ century when autograph manuscripts by authors first survive. ${ }^{19}$ By and large medieval scholars probably

${ }^{18}$ On Plutarch see C. Theander, Plutarch und die Geschichte (Lund: C. W. K. Gleerup, 1951) and W. C. Helbold and E. N. O'Neil, Plutarch's Quotations (Baltimore: American Philological Assocation, 1959). On Thucydides: W. K. Prentice, 'How Thucydides Wrote His History', Classical Philology 25 (1930): 117-127; Prentice argues that Thucydides' History is unfinished, gathered from sheets left loose in bundles at the author's death. On Diogenes Laertius see J. Mejer, Diogenes Laertius and His Hellenistic Background. Hermes Einzelschriften, Heft 40 (Wiesbaden: Frank Steiner Verlag, 1978).

${ }^{19}$ For a few examples see P. Glorieux, 'L'enseignement au moyen age. Techniques et méthodes,' Archives d'histoire doctrinale et littéraire du moyen âge (1968), 65-186, 178 [re Godefroy of Fontaines]. On autographs see A. Petrucci, Writers and Readers in Medieval Italy. Studies in the History of Written Culture, edited and translated by C. Radding (New Haven: Yale University Press, 1995), ch. 8; and Gli autografi medievali. Problemi paleografici e filologici, Atti del convegno di studio della Fondazione Ezio Franceschini, Erice 25 Settembre-2 Ottobre 1990, edited by P. Chiesa and L. Pinelli (Spoleto: Centro Italiano di studi sull'alto medioevo, 1994), especially J. Hamesse, 'Les autographes à l'époque scolastique. Approche terminologique et 
did not often take free-standing notes for long-term storage and re-use. Readers annotated manuscripts by writing in the margins, but separate notes were likely taken on temporary surfaces--wax tablets designed to be erased with a little heat and reused, or scraps of parchment which were much less costly than parchment sheets and not meant to be kept long-term. Though we rarely have detailed evidence of medieval working methods, in the case of Thomas Aquinas we can conclude from a lack of surviving notes and the testimony of contemporaries that he was an abundant author who did not rely on note-taking (pace Drexel who claimed that Aquinas 'must have excerpted' since he was such an abundant author). Because Thomas Aquinas attained a high status in his own lifetime, his few autograph manuscripts of his early works have been preserved. In this case at least we can conclude that if Aquinas had routinely taken reading notes on parchment we would know of them today. One of his secretaries reported instead that Aquinas composed by dictation from memory and from the books that his secretaries copied for him on request. ${ }^{20}$

We do have some evidence of medieval note-taking in the form of finished works which relied on notes taken from oral events (such as sermons and lectures) or on excerpts copied from other texts. The practice of writing down oral events has a long history, dating back to $4^{\text {th }}$ -

méthodologique', 179-205.

${ }^{20}$ On Aquinas's working methods see J. P. Torrell, Initiation à St Thomas d'Aquin (Cerf: Editions universitaires de Fribourg, 1993), 399-401; P. M. Gils, 'St Thomas écrivain', in S. Thomae de Aquino Opera omnia iussu Leonis XIII P. M. edita, tome 50 (Rome and Paris: Commissio Leonina, Editions du Cerf, 1992), 173-209 and especially A. Dondaine, Secrétaires de Saint Thomas, 2 vols (Rome: Commissio Leonina, 1956), vol. 1, 10-20. For Drexel's claim see Aurifodina, 42. 
century Athens at least, when Plato's dialogues and Aristotle's treatises were written down from oral teaching, likely by students whose work the master vetted. The medieval sermons that have come down to us also typically originated in notes taken by listeners (called reportationes), which the author of the sermon could correct, develop and vet before 'publishing' the finished sermon. ${ }^{21}$ Bernard of Clairvaux (1090-1153), whose 377 extant sermons form an exceptionally large corpus, composed his sermons in this way, relying on the notes taken by his secretary from his oral delivery. ${ }^{22}$ The notes taken in haste generally do not survive, but only the revised, finished texts; nonetheless in a few cases others present at the sermons circulated different, unauthorized versions of Bernard's preaching. ${ }^{23}$ Note-taking from sermons continued through the

${ }^{21}$ I use the term 'publish' to encompass not only publication through printing, but also the process of putting a manuscript into public circulation by making it available for copying. On the role of students in the formation of Aristotle's texts see Werner Jaeger, Aristotle: fundamentals of the history of his development, translated by Richard Robinson. Oxford: Clarendon Press, 1934), 317 and passim.

${ }^{22}$ See J. Leclercq, Etudes sur S. Bernard et le texte de ses écrits (Rome: apud Curiam Generalem Sacri Ordinis Cisterciensis, 1953), Analecta Cisterciensia 9 (1953), 45-67; and Nicole Bériou, 'Les sermons latins apres 1200,' in The Sermon, edited by B. Kienzle, Typologie des sources du moyen âge occidental fasc. 81-83 (Turnhout: Brepols, 2000), 363-448, at 365. Recent study of the sermons of St Augustine suggest that he similarly relied on the notes of 'stenographers'; see F. Dolbeau, Augustin et la prédication en Afrique. Recherches sur divers sermons authentiques, apocryphes ou anonymes (Paris: Institut d'Etudes Augustiniennes, 2005), 12.

${ }^{23}$ For one instance in which the note taken in haste can be compared with the finished version see 
early modern period. One of the most elaborate methods for writing down sermons, developed by the German pietist Hermann August Francke in the 1690s, involved enlisting students in his orphanage to work in teams to record sermons word for word: each note-taker would transcribe 10-12 words of the sermon in turn on slips of paper, which were then coordinated to reconstruct the full text. ${ }^{24}$ Similarly, many published lectures and textbooks from the middle ages and the early modern period originated with notes taken by students from the professor's oral delivery; the professor might vet these notes, or if the professor spoke at dictation speed (as in many early modern universities), students came away with fairly reliable copies of the course which they could publish posthumously. ${ }^{25}$

Another long-lived medieval genre, the florilegium, accumulated textual excerpts of the

N. Bériou, 'La réportation des sermons parisiens à la fin du XIIIe siècle', Medievo e Rinascimento (1989), 87-123, at 93-96.

${ }^{24}$ For more on this case among others, see A. Blair, 'Textbooks and Methods of Note-Taking in Early Modern Europe', in Scholarly Knowledge: the Transmission of Social Practice in Academic Textbooks 1450-1650, edited by E. Campi et al. (Geneva: Droz, 2008), 39-73. ${ }^{25}$ On the medieval context see L. Meier, 'Über den Zeugniswert der reportatio in der scholastik', Archiv für Kulturgeschichte 36 (1954) p. 1-8; I. Hajnal, L'enseignement de l'écriture aux universités médiévales, $2^{\text {nd }}$ edition, edited by L. Mezey (Budapest: Maison d'édition de l'Académie des Sciences de Hongrie, 1959), 117-23 (on dictation) and also A. Maierù, 'Les cours: lectio et lectio cursoria (d'après les statuts de Paris et d'Oxford', in L'enseignement des disciplines à la Faculté des arts, Paris et Oxford, XIIIe-XVe siècles, edited by O. Weijers and L. Holtz (Turnhout: Brepols, 1997), 372-91. 
kind that humanists would later recommend taking, also sorted under topical headings. Medieval florilegia generally emphasized passages from the Bible and the Church fathers, given their principal purpose as aids to sermon-writing, but their methods of excerpting were easily applied to ancient authors, in some medieval examples and in the many Renaissance florilegia which expanded on the medieval genre. Many of the works known as medieval 'encyclopedias' also copied or paraphrased excerpts from other sources on topics arranged systematically. Both genres offered ready-made the equivalent of reading notes which were valuable to preachers and other readers who lacked access to the works excerpted there. With the increased availability of books after printing, pedagogues called on young people and the adults they would become to make their own collections of notes from their reading, though many collections of excerpts were also available ready-made in print.

Factors explaining the rise of note-taking in the Renaissance:

The explosion of excerpting in the Renaissance can in part be explained by the use of paper. To be sure, temporary surfaces continued to be used in the early modern period: not only wax tablets but also new, pocket-sized tablets designed to be written on with a stylus and erased with a bit of moisture (recently brought to light by a team led by Peter Stallybrass) ${ }^{26}$ But paper became the medium of choice for scholarly note-taking, with the result that notes became much more durable. However, the first appearance, and even the first manufacture of paper in Europe predates by a considerable margin the evidence we have of bulk note-taking. Paper was first used in Europe as early as the $12^{\text {th }}$ century (imported to Genoa) and was manufactured in Italy in the

${ }^{26}$ P. Stallybrass, R. Chartier, J. F. Mowery and H. Wolfe, 'Hamlet's Tables and the Technologies of Writing in Renaissance England', Shakespeare Quarterly 55, 4 (2004), 379-419. 
$13^{\text {th }}$ century; paper use North of the Alps began in the $14^{\text {th }}$ century. ${ }^{27}$ The principal demand for paper before the invention of printing stemmed from the production of legal and administrative documents, rather than the needs of readers or authors. ${ }^{28}$ Paper was cheaper than parchment, by a factor of 8 at its first introduction in England, and by a factor of 32 in $1500 .{ }^{29}$ Yet parchment coexisted with paper until the mid- $15^{\text {th }}$ century as the medium used for copying manuscripts. A greater prevalence of paper for vernacular works and of parchment for religious works resulted from the fear articulated by contemporaries that paper would not prove as durable as parchment; Johannes Trithemius (1462-1516), a learned abbot known for his cantankerous response to printing, predicted the rapid deterioration of printed books because they were printed on paper. An Italian contemporary equally hostile to printed books, Vespasiano da Bisticci (1421-98), similarly commented that the manuscripts commissioned by Federigo, duke of Urbino, put printed books to shame 'because they were beautifully illuminated and written on parchment'. ${ }^{30}$

${ }^{27}$ For the impact of paper in Islam see J. Bloom, Paper before Print: The History and Impact of Paper in the Islamic World (New Haven: Yale University Press, 2001). A similar history of the arrival of paper in Europe is lacking. On Genoa see Petrucci, Writers and Readers, 153. For a timeline of the beginnings of paper-making in Europe see http://www.baph.org.uk/general\%20reference/early\%20history\%20of\%20paper.htm (consulted April 2008) and, for England, R. J. Lyall, 'Materials: The Paper Revolution', in Book Production and Publishing in Britain 1375-1475, edited by J. Griffiths and D. Pearsall (Cambridge:

Cambridge University Press, 1989), 11-29.

${ }^{28}$ Petrucci, Writers and Readers, 157.

${ }^{29}$ Lyall, 'Materials', 11.

${ }^{30}$ J. Trithemius, In Praise of Scribes. De laude scriptorum, translated by R. Behrendt (Lawrence, 
Printing, which spread rapidly after its invention in the 1450 s, triggered a vast new demand for paper and the creation of paper mills near every printing center. ${ }^{31}$ Although printing on parchment was technically feasible (and occasionally practiced, for example to produce one or two special presentation copies of a work), the cost of parchment negated the economic benefits of printing, so books were printed on paper.

The increased availability of paper coincided with a rise in paper records of all kinds, from diplomatic correspondence to family papers to collections of scholarly notes. ${ }^{32}$ But savvy users of paper for writing improved the paper produced for printing by sizing it with alum to

KS: Coronado Press, 1974), 35 (ch. 1). V. da Bisticci, Renaissance Princes, Popes, and Prelates. The Vespasiano Memoirs, translated by W. George and E. Waters (New York: Harper Torchbooks, 1963),104. On parchment versus paper see E. Kwakkel, 'A New Type of Book for a New Type of Reader: The Emergence of Paper in Vernacular Book Production', The Library 4 (2003), 219-48 and D. Booton, 'Notes on Manuscript Production and Valuation in Late Medieval Brittany', The Library 7:2 (2006): 127-152.

${ }^{31}$ C. de Hamel Christopher, Scribes and Illuminators (Toronto: University of Toronto Press, 1992), 16. On the foundation of paper mills see W. Weiss, Zeittafel zur Papiergeschichte (Leipzig: VEB Fachbuchverlag,1983), 62-69.

${ }^{32}$ See P. Dover, 'Deciphering the Diplomatic Archives of Fifteenth-Century Italy', Archival Science 7,4 (2007), 297-316, on the rise of diplomatic correspondence in fifteenth-century Italy, and Paston Letters and Papers of the Fifteenth Century, edited by N. Davis (Oxford: Oxford University Press, 2004) as an example of a large family archive formed in England between 1422 and 1509 . 
optimize its absorbency of quill as opposed to printer's ink. ${ }^{33}$ Thus Nicolas Fabri de Peiresc 'commonly caus[ed] all his Books, when they were in quires, to be washed over with Alumwater'. ${ }^{34}$ Peiresc prepared the books he owned for marginal annotations in this way and also by having additional blank pages bound into his books when the margins of the printed book seemed too narrow to allow for sufficient anntotation. Peiresc not only annotated his books himself, but also invited other scholars to read and annotate them. In the $17^{\text {th }}$ century (unlike in the $16^{\text {th }}$ century) paper used for printing was more often than not treated with alum too, and stationers offered an elaborate range of different kinds of paper, judging from the purchases Robert Boyle made of colored paper and inks to help him organize his notes (as Richard Yeo discusses in this volume). ${ }^{35}$

Paper was an important prerequisite for stockpiling notes on a large scale at much lesser cost than parchment allowed. Nonetheless paper alone cannot explain the tremendous enthusiasm for taking and saving notes in the Renaissance. The spread of a new cultural attitude was probably the most important factor driving the explosion of note-taking. The stockpiling of notes is one part of a larger cultural phenomenon of collecting and accumulating in early modern Europe

${ }^{33}$ On the process of sizing paper with alum, see D. Hunter, Papermaking through Eighteen Centuries (New York: W. E. Rudge, 1930), 140-41.

${ }^{34}$ Gassendi, The Mirrour of true nobility, book 6, 199.

${ }^{35}$ Only $26 \%$ of books printed in the $16^{\text {th }}$ century were sized with alum, while $72 \%$ of books in the $17^{\text {th }}$ century were, according to I. Brückle, 'The role of alum in historical papermaking', Abbey newsletter 17,4 (September 1993); read at http://cool.conservationus.org/byorg/abbey/an/an17/an17-4/an17-407.html (January 18, 2010). 
which generated not only textual compilations in manuscript and in print, but also all kinds of collections of natural and artificial objects, from plants and minerals to medals, paintings and 'curiosities'. ${ }^{36}$ Accumulation on a vast scale was not unprecedented in the Renaissance--after all Vincent of Beauvais's Speculum maius (1255) would hold its position, with its 4.5 million words, as the largest encyclopedic compilation down to the late $16^{\text {th }}$ century when it was overtaken by an expanded edition of Theodor Zwinger's Theatrum humanae vitae (1586). But Vincent's work was exceptional for its scope and size and introduced with a certain defensiveness that suggests that he feared it would come under attack on precisely those counts. Thus Vincent emphasized that his work was in fact brief and ancient:

$[\mathrm{T}]$ his new work is at the same time old, and it is also equally both brief and prolix. Indeed it is ancient by its authority and material, but new by the compilation and arrangement of its parts. And it is brief because of the reduction of many sayings to brevity. Nonetheless it is long because of the enormous multitude of material. ${ }^{37}$

\footnotetext{
${ }^{36}$ On the culture of collecting see for example Paula Findlen, Possessing Nature: museums, collecting and scientific culture in early modern Italy (Berkeley: University of California Press, 1994); O. Impey and A. MacGregor, The Origins of Museums: the cabinet of curiosities in sixteenth and seventeenth-century Europe (Oxford: Clarendon Press, 1985).

37 'Quoniam hoc ipsum opus novum quidem est simul et antiquum, breve quoque pariter et prolixum. Antiquum certe auctoritate et materia. Novum vero partium compilatione et earum aggregatione. Breve quoque propter multorum dictorum in breve perstrictionem. Longum nihilominus propter immensam materiae multitudinem.' Vincent of Beauvais, Bibliotheca mundi Vincentii Burgundi (Douai: Baltazar Bellerus, 1624), vol. I : Speculum naturale (Reprinted Graz: Akademische Druck- und Verlaganstalt,1964), col. 4 (prologue, 4).
} 
By contrast $16^{\text {th }}$-century compilers liberally displayed their hybristic ambitions to record all known books or even to rival the view God will have of all human behavior at the Last Judgment, as Zwinger did in his preface to the Theatrum:

Thus, having brought together in one place all the actions and passions of all men who have lived from the beginning of the world to its end, we may be allowed to wish rather than to hope that this Theatrum, finally perfected, would resemble in some way that censorious display before the most just Judge. ${ }^{38}$

Other aspects of this complex transition from medieval to early modern include the shift in the valence of curiosity from vice to virtue, bolder claims for innovation, and an attenuated emphasis on ancient authority. ${ }^{39}$

Explaining the exuberance for accumulating information must also be complex. The

38 'Non vetustate tantum, sed varietate et copia commendantur historiae: atque ut humanam universitatem non qui fuerunt tantum, non qui nunc sunt, non qui erunt olim homines constituere dicuntur, sed omnes simul. Ita quod tamen optare potius quam sperare licet, omnibus omnium hominum, qui a primo mundi ortu ad excidium usque vixerunt, actionibus et passionibus in unum collatis, perfectum demum et censoriae illius coram iustissimo Judice panegyris aliqua ex parte aemulum foret Theatrum.' T. Zwinger, Theatrum humanae vitae (Basel,1586), sig. **3v. For more discussion of this preface see Ann Blair, 'Historia in Theodor. Zwinger's Theatrum humanae vitae', in Historia: Empiricism and Erudition in Early Modern Europe, edited by G. Pomata and N. Siraisi (Cambridge, Mass.: MIT Press, 2005), 269-96.

${ }^{39}$ On curiosity see for example N. Kenny, Curiosity in Early Modern Europe: Word Histories (Wiesbaden: Harrassowitz, 1998) and The Uses of Curiosity in Early Modern France and Germany (Oxford: Oxford University Press, 2004). 
Renaissance experienced an influx of all kinds of new information-ancient texts newly recovered by the humanists and accounts of the new worlds and newly explored old worlds, so there was much to record. But this influx in itself also does not explain why Europeans were obsessed with recording this new information-they could have ignored it rather than seeking it out. Indeed the abundance of new natural specimens collected in the $16^{\text {th }}$ and $17^{\text {th }}$ centuries stemmed just as much from discoveries made within Europe as from those made overseas; in both cases a new attentiveness to observation and recording observation was the underlying innnovation. ${ }^{40}$ Crucial to the new emphasis on stockpiling information was a keen awareness of the loss of ancient learning which was central to the humanist project of recovering ancient language, literature and culture: humanists sought to ward off any similarly catastrophic loss in the future by accumulating learning in multiple forms. The Zurich polymath Conrad Gesner (1516-65) called on princes to fund libraries to ensure that books would never again be lost on such a scale. In his Bibliotheca Universalis (Universal bibliography) of 1545 he accumulated information about every known text in Latin, Greek and Hebrew. Gesner felt it was important not to make selections, but to be exhaustive in his listing. ${ }^{41} \mathrm{He}$ justified this policy by repeating the principle

\footnotetext{
${ }^{40}$ See B. Ogilvie, The Science of Describing (Chicago: University of Chicago Press, 2006), 230; and A. Cooper, Inventing the Indigenous: Local Knowledge and Natural History in Early Modern Europe (Cambridge: Cambridge University Press, 2007).

${ }^{41}$ 'Nullus a me scriptor contemptus est, non tam quod omnes catalogo aut memoria dignos existimarem, quam ut instituto meo satisfacerem, quo mihi imperaveram sine delectu simpliciter omnia quae incidissent commemorare. ... Nos recitare tantum voluimus, delectum iudiciumque liberum reliquimus alijs.' C. Gesner, Bibliotheca universalis (Zurich, 1545), sig. *2v, *3v.
} 
attributed to Pliny the Elder, that there is no book so bad that some good cannot be got of it. He also explained that tastes change over time, so that a book once considered bad might be valued later on - hence again the importance of eliminating nothing from the stock of information about books. $^{42}$

Similarly the abundant note-taker Nicolas Fabri de Peiresc was loath to let any observation go unrecorded lest it prove useful to someone at some point. His biographer reported that Peiresc was most diligent in writing down 'any notable thing came into his mind, or was suggested by some other or observed in reading' because he could 'never endure that the least invention or observation of any man should be lost, being alwayes in hopes that either himself, or some other, would be advantaged thereby'. Therefore 'he wrote things down in his memorials because he then judged they were out of danger of being forgotten'. ${ }^{43}$ Joachim Jungius too, who

$\overline{42}$ 'Multi in uno loco vulgares et utiles sunt, ijdem alibi rarissimi, aut plane incogniti: et qui olim tritissimi erant, nunc in nullo sunt usus studiorum: ... Plurimi hodie authores omnibus notissimi sunt, qui prodculdubio post centum annos paucissimis cogniti in tenebris latebunt. ... Virgilius ex stercore Ennij legebat aurum, et Plinius dictitabat, nullum esse tam malum librum, qui non aliqua ex parte prosit. Duplex sane barbarorum genus existit: sunt qui dicendo tantum barbari, res interim bonas et utiles doceant, quos modis omnibus conservari par est....' Gesner, Bibliotheca, sig. *3v; on Gesner's keen awareness of loss, see Jan-Dirk Müller, 'Wissen ohne Subjekt? Zu den Ausgaben von Gesners Bibliotheca universalis im 16. Jahrhundert', in Zukunft der Literatur-Literatur der Zukunft: Gegenwartsliteratur und Literaturwissenschaft, edited by R. Sorg, A. Mettauer and W. Pross (Munich: Wilhelm Fink, 2003), 73-91, at 80.

${ }^{43}$ Gassendi, The mirrour of true nobility, 191-92. 
may have accumulated the most notes of any of his contemporaries, emphasized that every discipline taught something of worth; of his student Michael Kirsten a contemporary reported that 'there was no field in which he had not read, taken notes and written commentaries'. ${ }^{44}$

Printing may also have encouraged new attitudes toward the accumulation of manuscript materials by offering the potential for publishing them and the hope of thereby enhancing one's reputation and/or one's finances. Along with other factors (such as improvements in postal systems), printing likely heightened the sense of working toward a common good for an international Republic of Letters, which motivated some abundant note-takers and collectors in the early modern period, such as Nicolas Fabri de Peiresc who shared generously from his notes with correspondents across Europe.

Kinds of note-taking:

Note-taking was taught in schools in the wake of humanism in two principal ways. On the one hand adolescents studied the Latin classics (such as Ovid, Vergil and Cicero) under the direction of a master who commented on the text, explaining its grammar, figures of speech and cultural references. This teaching generated printed schooltexts which pupils annotated heavily in the margins, between the printed lines and often on blank pages added for the purpose. Judging from the near-identical notes taken by different students in the same class, they were taken under dictation by the master. Notes of this kind survive abundantly from certain contexts,

${ }^{44}$ Meinel, 'Enzyklopädie der Welt', 167. 'Nulla propemodum est disciplina, nulla superiorum, quas dicunt facultatum, in qua Kirstenius non aliquid legerit, excerpserit, ipse scripserit ac commentatus sit'. Catalogus librorum Michaelis Kirstenii Moravi (Hamburg, 1679), sig )o( 2r. 
such as Leipzig in the 1510s and the collèges of the University of Paris in the 1560s-1580s; the reasons for this distribution are not yet understood and could include preservation patterns as well as changing teaching methods. ${ }^{45}$ On the other hand humanist pedagogues encouraged their pupils to read independently and to keep reading notes which would be inspected by the master. Schoolboys kept notebooks by selecting from assigned authors bits deemed of value either for their rhetorical interest or for their historical examples. These schoolboy notebooks are much less well preserved than the reading notes kept by adults or the notes written in printed books which were often cataloged by libraries for their printed text. Nonetheless we know of at least one complete set of notebooks kept by a pupil aged 11-15. August, future Duke of Brunswick (15791666), founded a library at Wolfenbüttel that now bears his name and preserved there the notebooks he kept as a boy. Gilbert Hess has shown how August flagged passages in the books he read (notably Cicero's De officiis), with underlining and a few 'Nota's or pointing fingers, then copied select passages into a Sentenzensammlung (collection of sententiae or memorable sayings) in the order of their appearance in the text. August then recopied many of the same excerpts as well as passages from other sources in a second notebook arranged by topical headings. ${ }^{46}$ This method of double copying of the passages to retain was advocated by

45 J. Leonhardt, 'Classics as textbooks: A study of the humanist lectures on Cicero at the University of Leipzig ca. 1515', in Scholarly Knowledge (note 24), pp. 89-112; A. Blair, 'Ovidius Methodizatus: the Metamorphoses of Ovid in a Sixteenth-Century Paris Collège', History of Universities 9 (1990), 73-118 and A. Grafton, 'Teacher, Text and Classroom: a study from a Parisian Collège', History of Universities 1 (1981), 37-70.

${ }^{46}$ G. Hess, 'Fundamenta fürstlicher Tugend. Zum Stellenwert der Sentenz im Rahmen der 
Renaissance pedagogues, notably the Jesuit Francesco Sacchini. The act of writing itself was widely thought to aid retention because 'what is copied is impressed on the mind more thoroughly.' Sacchini praised writing for forcing the mind to slow down while reading and attend to the text more carefully; Juan Luis Vives (1492-1540) also praised the act of writing for keeping light or scabrous thoughts at bay. ${ }^{47}$

Many adults were no doubt only too happy to cease note-taking once they left school, but those who continued in a life of learning often continued to take notes, though they rarely followed the demanding precepts taught in school. As adults even diligent note-takers took liberties with the model of double copying. Indeed the Jesuit pedagogue Jeremias Drexel

voruniversitären Ausbildung Herzog August d. J.' in Sammeln, ordnen, veranschaulichen, edited by F. Büttner et al. (Münster: LIT Verlag, 2003), 131-174.

47 'Prima est: Lectoris intentio scribendi et annotandi cura multum acuitur. ... Altera ratio est. Quod exscribitur, intelligentiam profundius subit, menti altius imprimitur.' Drexel, Aurifodina, 56; and Sacchini, De ratione libros cum profectu legendi libellus, 74: 'Deinde ipsa quoque scriptio et intelligentiam iuvat.' On Vives, see A. Moss, Printed Commonplace-Books and the Structuring of Renaissance Thought (Oxford: Clarendon Press, 1996), 300, quotation \#125. For other articulations of this notion see Gassendi, The True mirrour of nobility, book 6, 191 and Richard Steele, "What are the Hindrances and Helps to a Good Memory in Spiritual Things?" in $A$ Continuation of Morning-Exercise Questions ... resolved in 1682, edited by S. Annesley (London: J.A. Dunton, 1683), 428, as quoted in T. Knoles and L. Z. Knoles, '"In Usum Pupillorum": Student-Transcribed Texts at Harvard College before 1740', in T. Knoles, R. Kennedy and L. Z. Knoles, Student Notebooks at Colonial Harvard: Manuscripts and Educational Practice, 16501740 (Worcester, MA: American Antiquarian Society, 2003), 7-88, 57. 
advocated instead indexing one's notes to ensure retrievability and acknowledged that note-takers should develop their own habits: 'if these precepts and rules of note-taking do not please you, draw up other precepts for yourself, fewer in number, shorter, suited to your studies, just as long as you take notes. ${ }^{48}$ The manuals of both Sacchini and Drexel were reprinted multiple times through the $18^{\text {th }}$ century, and starting in the late $17^{\text {th }}$ century advice on note-taking was also available in the vernaculars, in English, French and German. ${ }^{49}$ Charles Sorel described the system of multiple

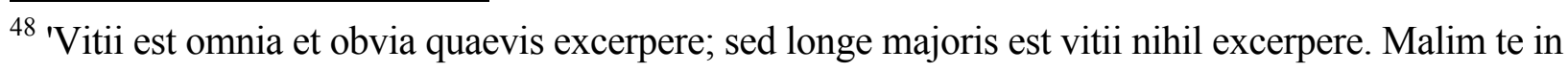
illam, quam istam culpam incidere. Hic ergo saepius monendi sumus: Quod facis, fac cum judicio.' Drexel, Aurifodina, 83. 'Quod si praeceptiones istae et Excerpendi leges non placeant, scribe tibi alias, pauciores, breviores, studiis tuis commodas, dummodo Excerpas. Hoc autem vere TUUM dixeris, quod in rem tuam cum judicio excerpseris.' Drexel, sig [A8]r.

${ }^{49}$ Sacchini was reprinted in Saint-Mihiel (Lorraine), 1615, Ingolstadt 1616, Bordeaux 1617, Dillingen 1621, Leipzig 1711 and 1738 and Vannes (Brittany), 1866; and translated into French (The Hague, 1786) and German (Karlsruhe,1832). Drexel's Aurifodina was reprinted in Antwerp 1641, 1642, 1657, 1658, 1691; Cologne 1638 and 1643; Munich 1642; Bratislava 1659; Frankfurt 1670; n. pl. 1671; Lyon 1675; and Naumburg 1695, as discussed in H. Zedelmaier, 'Johann Jakob Moser et l'organisation érudite du savoir à l'époque moderne', in Lire, copier, écrire, edited by E. Décultot (Paris: CNRS, 2003), 43-62, 54. Vernacular advice books include C. Sorel, Supplement des traitez de la connaissance des bons livres (Paris, 1673); F. de La Mothe Le Vayer, Observations diverses sur la composition et sur la lecture des livres (Paris, 1668); J. C. Udenius, Excerpendi ratio nova (Nordhausen, 1684) and D. Wheare, The Method and Order of Reading Both Civil and 
notebooks but also described some of the shortcuts used by scholars who left 'ordinary commonplacing to schoolboys': they selected headings from printed reference works, abbreviated words in copying them, copied nothing from books they owned, but only marked passages with different symbols (lines, crosses, circles, etc.) to denote their interest. Sorel was confident that the latter method saved days of work and that the symbols were effective in bringing back to mind 'all the things that he read before with pleasure and that makes him remember all the rest'..$^{50}$ But collections of notes were often hard to navigate: symbols without keys and the complex arrangement of papers were obscure even to the immediate contemporaries who inherited the collections, and in some cases to the note-takers themselves (see Leibniz's complaint cited by Richard Yeo in this volume), let alone to historians centuries later.

Ecclesiastical Histories (London, 1685). For a selection of translations into modern Italian from note-taking manuals, see A. Cevolini, De arte excerpendi. Imparare a dimenticare nella modernità._Biblioteca dell'Archivum Romanicum, Serie I: Storia, Letteratura, Paleografia; 333 (Florence: Leo S. Olschki Editore 2006).

50 '[Le gens d'etude] laissent donc les Lieux communs ordinaires pour les Escholiers. ... Ils ne font que les marques de crayon aux Marges et sur les Lignes; cela est de grande utilité quand mesme avec cela on feroit des Recueils ou des Tables, pource qu'en moins d'une demy-heure, un homme fait la reveue d'un Livre dont la lecture entiere luy auroit couté quatre ou cinq jours, et par le moyen de ses marques qu'il reconnoist aussi-tost et qui sont aux lieux les plus signalez, ils retrouve toutes les chose qu'il a leues autresfois avec plaisir, et cela le fait aussi ressouvenir de tout le reste.' Sorel, Supplement, 12 (and 8-14 more generally). 
Despite the idiosyncracies of their system of note-taking abundant note-takers often envisioned their notes serving others after them, though such hopes were probably often illusory. Leonardo da Vinci (1452-1519) developed an idiosyncratic hand-writing in the 6500 pages that survive from an original collection which was no doubt much larger, containing reading excerpts as well as sketches for machines and concepts typically never taken to fruition. These notes were unusually personal yet Leonardo bequeathed them to his pupil Francesco Melzi presumably with the expectation that the latter or others might make some use of them. Instead the notebooks came to scholarly attention only much later. ${ }^{51}$ Similarly notebooks were specifically mentioned in wills to ensure their safekeeping and bequest to a son or a grandson. ${ }^{52}$ Occasionally the heir would add further references to a notebook (as the younger Robert Sidney did in his father's commonplace book) or would use it in his studies (as copies of Harvard courses were passed down to youger students). ${ }^{53}$ The most effective method of sharing one's notes was to publish them, along with

${ }^{51}$ R. Zwijnenberg, Robert, The Writing and Drawings of Leonardo da Vinci (Cambridge: Cambridge University Press, 1999).

${ }^{52}$ P. Beal, 'Notions in Garrison: The Seventeenth Century Commonplace Book', in New Ways of Looking at Old Texts: Papers of the Renaissance English Society, 1985-1991, edited by W. S. Hill (Binghamton, NY: MRTS in conjunction with the Renaissance English Text Society, 1993), 131-47, 134; R. Yeo, 'A Philosopher and his Notebooks: John Locke (1632-1704) on Memory and Information', Griffith University Professorial Lecture Series no. 4 (2004), available on-line at http://www.griffith.edu.au/ins/collections/proflects/content2.html.

${ }^{53}$ G. Warkentin, 'Humanism in Hard Times: The Second Earl of Leicester (1595-1677) and His Commonplace Books, 1630-60', in Challenging Humanism: Essays in Honour of Dominic 
finding devices to help readers find what they were seeking. I argue elsewhere that many of the large compilations published in the Renaissance originated in the stockpiled notes produced in a lifetime of reading and teaching. Some were arranged miscellaneously in the order of reading and boasted of offering variety and pleasure on the model of the Attic nights of the ancient Aulus Gellius. Other compilations were structured under commonplace headings arranged systematically or alphabetically. These printed collections of notes supplied headings and contents for others to use in their note-taking or their compositions. ${ }^{54}$

Early modern note-taking was often a shared activity, although the helpers are typically hard to learn about. Scholars worked with amanuenses who might be assigned a theme or a book on which to take notes or to write notes or new prose under dictation (Michel de Montaigne composed by dictation sometimes, and Robert Boyle when he suffered from an eye ailment). ${ }^{55}$ Bartholomaeus Keckermann (1573-1609), professor of physics, logic and theology at Dantzig, was credited by a contemporary with being the first to recommend that students work in small groups or collegia of three to six students: he enjoined students of similar abilities, interests and level to

Baker-Smith, edited by T. Hoenselaars and A. Kinney (Newark: University of Delaware Press, 2005), 229-53, 238-40; on Harvard college notes, see Knoles and Knoles, '"In Usum Pupillorum"', 37.

${ }^{54}$ A. Blair, Too Much To Know: managing scholarly information before the modern age (New Haven: Yale University Press, 2010).

${ }^{55}$ On Boyle's amanuenses and their high turnover, see Works of Robert Boyle, 14 vols, edited by M. Hunter and E. B. Davis (London: Pickering and Chatto, 1999-2000), vol. 1, ci; on Montaigne see G. Hoffmann, Montaigne's Career (Oxford: Clarendon Press, 1998), 45-54. 
discuss and pool together their notes, then each student would make a copy of the collective notes for his own use. ${ }^{56}$ Enlisting the help of others certainly made it easier to accumulate notes on a large scale.

Another related innovation in early modern note-taking methods was the use of the slip, not a standard-sized index card but a sheet of paper written on one side and cut up into slips to make each recorded item available to be moved around and combined with other notes in different ways (using whole sheets of paper as loose leaves presented some of the same advantages of mobility, though full sheets could not be combined on one page like slips). Naturalists like Conrad Gesner and Ulisse Aldrovandi used slips to accumulate material which they could then arrange easily in alphabetical or systematic order. We do not know how the slips were stored when loose (possibly in pigeonholes, baskets or bags) because they survive tipped into bound volumes or (most commonly) glued onto the sheets of a notebook, which was likely the final purpose for which they were saved--in the $16^{\text {th }}$ century slips were not considered a

56 'Socialium Excerptorum primus mentionem, quod sciam, fecit KECKERM. Cons. log. de adornandis Locis Communibus c.1.p.3 columna 2. circa finem: exponens, quomodo plures conjungere possent operam suam in excerpendo.' V. Placcius, De arte excerpendi, vom Gelährten Buchhalten liber singularis quo genera et praecepta excerpendi (Stockholm and Hamburg, 1589), 161. On Keckermann's collegia see H. Hotson, Commonplace Learning: Ramism and its German Ramifications, 1543-1630 (Oxford: Oxford University Press, 2007), 241-42 and B. Keckermann, 'Consilium logicum de adornandis et colligendis locis communibus, rerum et verborum', in Opera omnia, 2 vols. (Geneva, 1614), vol. 2, cols. 220-42 at cols. 222-223 [misnumbered 220-221]. 
medium for permanent storage, but a temporary state used for gathering and sorting material. ${ }^{57}$ But in 1689 Vincent Placcius published a description of a note closet devised in the 1640s by Thomas Harrison which could store loose slips under topical headings: in addition to the flexibility in rearranging the slips, Placcius boasted of the closet's value for group work since notes could be contributed by many and shared among many without harming access to the bulk of the material stored there (whereas a notebook once lent out is no longer accessible). ${ }^{58}$ Although the closet was probably rarely made (only two examples are known to have existed, Placcius' own and one made for Leibniz, neither of which survive), its description in print attests to and may have helped to inspire experimentation with idiosyncratic methods of note-taking. ${ }^{59}$ Certainly we know that such experimentation continued in the $18^{\text {th }}$ century, alongside more conventional methods like those advocated by Sacchini and Drexel. The German jurist Johann Jacob Moser (1701-85) and and the Swiss physiognomist Johann Kaspar Lavater (1741-1801) also kept their notes on cards stored in boxes, while the Zurich scholar Caspar Hagenbuch formed his notebooks by copying out the headings from books matching their layout on the pages of his notebook and filling in the blank space with excerpts. ${ }^{60}$

\footnotetext{
${ }^{57}$ Meinel, 'Enzyklopädie der Welt und Verzettelung des Wissens', 170.

${ }^{58}$ Placcius, De arte excerpendi, 121-59; Noel Malcolm, 'Thomas Harrison and his 'Ark of studies': an episode in the history of the organization of knowledge', The Seventeenth Century 19 (2004): 196-232. For more discussion see also Blair, Too Much To Know, ch. 2.

${ }^{59}$ Von Murr reports that Leibniz purchased the closet at the death of Clacius, Hanoverian secretary, who had had it made for him. C. G. von Murr, Journal zur Kunstgeschichte und zur allgemainen Litteratur,7ter Teil (Nurnberg, 1779), 211.

${ }^{60}$ Décultot, Lire, copier, écrire, 15. On Moser see Zedelmaier, 'Johann Jakob Moser', 51ff; on
} 
The history of note-taking has only begun to be written. On the one hand the basic functions of selecting, summarizing, storing and sorting information garnered from reading, listening, observing and thinking can be identified in most literate contexts in some form or other. On the other hand Renaissance humanists emphasized with unprecedented success the virtues of stockpiling notes on large scales and for the long term, thanks to the availability of paper and a new abundance of books, but also to their ability to transmit their own keen motivation to avoid any future loss of learning. We continue to share many early modern ideals for insuring the collection and retrievability of information and have built on early modern practices that facilitate the accumulation and the organization of information, including collaborative work and the use of rearrangeable slips. But in the last decades we have begun to transfer these long-standing goals and techniques to a range of new electronic technologies and media. In doing so we would do well to appreciate the thoughtful attention with which early modern scholars tried to store information so that it remained accessible for different purposes and different users long after the initial selection. In particular we should be concerned about replicating the staying power of writing on electronic media that become obsolete multiple times even in one lifespan. Will we, let alone anyone else, be able to read the notes we take now, once they cease to seem relevant enough to warrant uploading onto the latest hardware and software? As we shift to forms of note-taking that are not as ephemeral as the wax tablets but also not as durable as ink on paper, we may be limiting the history of note-taking to a few centuries between

Hagenbuch: Klaus Weimar, 'Les comptes savants de Johann Caspar Hagenbuch', in Lire, copier, écrire, 65-78; I am grateful to Klaus Weimar for telling me of the notes of Lavater, in the manuscript collection of the Zentralbibliothek Zürich. 
Renaissance and the digital revolution. Thankfully there is much to explore among the notes surviving from those centuries, from which we stand to gain both as historians and as modern practitioners of the ars excerpendi.

Dept of History, Harvard University 